Annals of International Medical and Dental Research

E-ISSN: 2395-2822 | P-ISSN: 2395-2814

Vol-8, Issue-1 | January-February 2022

DOI: 10.53339/aimdr.2022.8.1.45

Page no- 358-367 | Section- Research Article (Medicine)

\title{
Determination of Serum Thyroglobulin Concentration in Simple Diffuse Goiter Patients with Known Iodine Status
}

\author{
Muhammad Abdul Halim Khan ${ }^{*}$, Md. Farid Uddin², M. A. Hasanat ${ }^{3}$, Jobaida Naznin ${ }^{4}$, Ashim \\ Dhar $^{5}$
}

\begin{abstract}
${ }^{1}$ Assistant Professor, Department of Endocrinology, Shaheed Suharawardy Medical College \& Hospital, Dhaka, Bangladesh.

Email: dr.mahalimkhan@gmail.com

Orcid ID: 0000-0002-3459-2708

2Professor, Department of Endocrinology, Bangabandhu Sheikh Mujib Medical University, Dhaka, Bangladesh.

Email: dr.md.fariduddin@gmail.com

Orcid ID: 0000-0002-7537-0933

3Professor, Department of Endocrinology, Bangabandhu Sheikh Mujib Medical University, Dhaka, Bangladesh.

Email: hasnat_endro@bsmmu.edu.bd

Orcid ID: 0000-0001-8151-9792

${ }^{4}$ Assistant Professor, Department of Endocrinology, Shaheed Suharawardy Medical College \& Hospital, Dhaka, Bangladesh.

Email: urmi512@gmail.com

Orcid ID: 0000-0002-0944-0593

${ }^{5}$ Medical Officer, Department of Endocrinology, Shaheed Suharawardy Medical College \& Hospital, Dhaka, Bangladesh.

Email: ashimcda@gmail.com

Orcid ID: 0000-0002-6837-0089

*Corresponding author

Received: 20 August 2021

Revised: 20 November 2021

Accepted: 06 December 2021

Abstract

Background: Thyroglobulin (TG) seems to be a valuable indicator of thyroid function and iodine nutrition status. Aim of the study: The aim of the study was to observe the relationship between serum thyroglobulin and urinary iodine (UI) in simple diffuse goiter patients. Methods: This cross-sectional observational study was conducted at the Department of Endocrinology, Bangabandhu Sheikh Mujib Medical University, Dhaka, Bangladesh. The study duration was 2 years, starting from May 2014 to March 2016. Total 87 patients with simple diffuse goiter attending the OPD Department of Endocrinology of BSMMU had been recruited as study population. A purposive sampling technique was followed for sample selection. Results: Serum thyroglobulin $(\mathrm{ng} / \mathrm{mL}$, mean $\pm \mathrm{SD}$ and median) was lowest in the age group $12-16$ years $(6.0 \pm 4.5,5.16 \mathrm{ng} / \mathrm{mL})$ followed by age $>31$ years $(8.8 \pm 8.1$, $6.16 \mathrm{ng} / \mathrm{mL}$ ), whereas other age groups showed level around 13.0 and 10.0 $\mathrm{ng} / \mathrm{mL}(\mathrm{p}=0.520)$. Mean $( \pm S D)$ Urinary Iodine was not statistically different among age groups ( $347.4 \pm 226.5$ vs. $337.08 \pm 188.9$ vs. $300.5 \pm 95.37$ vs. $337.7 \pm$ 225.42 vs. $278.3 \pm 105.7, \mu \mathrm{g} / \mathrm{L}$; F $0.451, \mathrm{p}=0.771$ ) while median values were 325.26 vs. 355.68 vs. 325.80 vs. 338.86 and $300.90 \mu \mathrm{g} / \mathrm{L}$ respectively. Neither thyroglobulin $(5.76 \pm 5.72$ vs. $11.60 \pm 13.50 ; 3.47$ vs. $8.9 \mathrm{ng} / \mathrm{mL}, \mathrm{m} \pm \mathrm{SD}$ and median; $\mathrm{p}=0.294)$ nor Urinary Iodine $(373.5 \pm 44.5$ vs. $317.2 \pm 180.32 ; 378.1$ vs. $308.9 \mu \mathrm{g} / \mathrm{L}, \mathrm{m} \pm \mathrm{SD}$ and median; $\mathrm{p}=0.450$ ) were statistically different between the gender groups. Similarly, thyroglobulin and Urinary Iodine were also statistically similar for grade- 1 and grade- 2 goiter (thyroglobulin: $6.79 \pm 4.33$ vs. $11.67 \pm 13.69$ and 6.74 vs. $8.02 \mathrm{ng} / \mathrm{mL}, \mathrm{m} \pm \mathrm{SD}$ and median, $\mathrm{p}=0.319$; Urinary Iodine: $361.33 \pm 51.60$ vs. $317.09 \pm 182.44,362.69$ vs. $305.35 \mu \mathrm{g} / \mathrm{L}, \mathrm{m} \pm \mathrm{SD}$ and median, $\mathrm{p}=0.498$ ). Conclusion: Thyroglobulin seems to have an inverse association in iodine deficiency state and positive association in over sufficient state with UI. There was no statistically significant difference of TG concentration between males and females nor between Grade- 1 and Grade2 goiter.
\end{abstract}

Published: 22 December 2021

Keywords:- Goiter, Diffuse, Thyroglobulin, Iodine, Deficiency.

\section{INTRODUCTION}

Thyroid disorder is one of the major health problems in many countries including
Bangladesh.[1] The spectrum and the prevalence of thyroid disorders are influenced by iodine intake. [2] Iodine deficiency may cause goiter in 
Annals of International Medical and Dental Research

E-ISSN: 2395-2822 | P-ISSN: 2395-2814

Vol-8, Issue-1 | January-February 2022

DOI: $10.53339 /$ aimdr.2022.8.1.45

Page no- 358-367 | Section- Research Article (Medicine)

all age groups, which is the enlargement of the thyroid gland.[3] Palpable thyroid enlargement is common, affecting about $5 \%$ of the global population. [4] Goiter may be classified into toxic or nontoxic according to patient's clinical status, diffuse or nodular according to its anatomic nature, and endemic or sporadic according to epidemiologically. A diffuse enlargement of thyroid gland in the absence of nodules and hyperthyroidism is referred to as simple goiter.[5] Simple diffuse goiter (SDG) is more prevalent in areas with a low iodine intake.[6] Iodine is an essential component of thyroid hormones, which participate in the normal mental and physical development and maintenances of homeostasis in humans.[7] They regulate many key biochemical reactions, especially protein synthesis and enzymatic activity. Simple diffuse goiter or diffuse nontoxic or colloid goiter is soft, symmetrical and the gland is enlarged two to three times its normal size. Serum level of T3, T4 and TSH are normal and no thyroid auto-antibodies are detected in the serum. This form of goiter usually presents between the ages of 15 to 25 years, during pregnancy it tends to be noticed not by the patient but by friends and relatives. [] Though iodine deficiency is the main cause of simple diffuse goiter, puberty, pregnancy, excess iodine, exogenous goitrogen, genetic factors and the socioeconomic conditions play a role in goiter formation. Due to the high prevalence of simple diffuse goiter (SDG) in areas with lacking iodine among the population, it is often termed as endemic goiter. The great arc of the Himalayas from Pakistan across India, Nepal, Northern Thailand, Vietnam and Indonesia are some of the most highly endemic regions of the world. For the synthesis of thyroid hormone, iodine is an essential trace element required. Through an effect on oxygen consumption and heat production, growth, reproduction, neuromuscular function, skin and hair growth and cellular metabolism, these hormones regulate a large number of activities, which include energy transformation. $20-30 \mathrm{mg}$ of iodine normally contain in the body. About 60 percent of it is in the thyroid gland and rest is diffused throughout all tissues, especially in the ovaries, muscles and blood. For assessing the impact of the Universal Salt iodization (USI) program, and to ensure sustainability, the World Health Organization (WHO) has recommended the measurement of urinary iodine as the standard method to assess the dietary intake of iodine by the community.[4] Urinary iodine excretion is a good marker of dietary intake of iodine. The value of thyroglobulin as an indicator of global Iodine Deficiency Disorder (IDD) status has not yet to be fully explored, but the results from population studies show that thyroglobulin seems to be a valuable indicator of thyroid status in respect to its sensitivity to recent changes in iodine nutrition. $[9,10]$ Thyroglobulin may be a promising functional biomarker of both iodine deficiency and excess iodine intake.[10]

\section{Objective}

\section{General Objective:}

- To observe serum thyroglobulin levels in simple diffuse goiter patients

- To observe urinary iodine levels in simple diffuse goiter patients

\section{Specific Objectives}

- To observe the relationship between serum thyroglobulin and urinary iodine levels in simple diffuse goiter patients 
Annals of International Medical and Dental Research

E-ISSN: 2395-2822 | P-ISSN: 2395-2814

Vol-8, Issue-1 | January-February 2022

DOI: $10.53339 /$ aimdr.2022.8.1.45

Page no- 358-367 | Section- Research Article (Medicine)

\section{MATERIAL AND METHODS}

This cross-sectional observational study was conducted at the Department of Endocrinology, Bangabandhu Sheikh Mujib Medical University, Dhaka Bangladesh. The study duration was 2 years from May 2014 to March 2016. Total 87 patients with simple diffuse goiter attending the OPD Department of Endocrinology of the study hospital had been recruited as study population. A purposive sampling technique as per inclusion and exclusion criteria was followed for sample selection. Written Informed consent was taken from all patients after completely explaining procedure, purpose, risk and utility of the study. Prior to commencement of this study the research protocol was approved by Institutional Review Board. Blood sample $(5 \mathrm{ml})$ was collected from each patient by researcher himself and after separation of serum it was send to the laboratory of NINMAS, BSMMU without delay for analysis of serum thyroglobulin.

\section{Inclusion Criteria}

- Subjects who had diffusely enlarged thyroid gland and clinically, biochemically in euthyroid state.

- Age group 12-35 yrs.

Exclusion Criteria

- Patients with suspected differentiated thyroid cancer

- Patients with acute and chronic illness

- Pregnant and lactating mothers

- Patient taking drug interfering in thyroid function test.

- Patients with thyroiditis or Graves' disease

- Patients with unilateral goiter

- Patients with nodular goiter

\section{RESULTS}

[Table 1] stated that, among total 87 patients, 29 $(33.3 \%)$ of the participants were from the age group of 17-21 years, $16.1 \%$ from $22-26$ years of age group, $18.4 \%$ from the age group of $27-31$ years, and $12.6 \%$ were aged between 12-16 years, and $19.5 \%$ were older than 31 years. The Mean \pm SD age was $23.97 \pm 6.83$ years.

[Figure 1] showed, 17-21 years group is higher $33.3 \%$ followed by $>31$ years $19.5 \%$ and $27-31$ years $18.4 \%$.

[Figure 2] showed, among the participants, $81(93 \%)$ were female and only $6(7 \%)$ were male. The male: female ratio was 1:14.5

[Table 2] showed, the lowest level of serum thyroglobulin $(\mathrm{ng} / \mathrm{mL})$ found in the age group $12-16$ years of age $(6.0 \pm 4.5 \mathrm{ng} / \mathrm{mL})$ followed by participants aged over 31 years (8.8 \pm 8.1 $\mathrm{ng} / \mathrm{mL})$, whereas other age groups showed serum thyroglobulin levels of around 13.0 ng/mL (Age 17-21 years: $12.9 \pm 18.0$; 22-26 years: $12.8 \pm 12.2$; $27-31$ years: $12.9 \pm 11.4$ ). There was no statistically significant different among these age groups for thyroglobulin $(p=0.520)$. The median values for age groups 12-16 years, 17-21 years, 22-26 years, 27-31 years and $>31$ years were $5.16,9.42,10.63,9.79$ and 6.16 respectively.

According [Table 3], the mean urinary iodine was not statistically different among these age group $(\mathrm{p}=0.771)$. The values were $($ mean $\pm S D)$ 347.4 $\pm 226.5, \quad 337.08 \pm 188.9, \quad 300.5 \pm 95.37$, $337.7 \pm 225.42,278.3 \pm 105.7 \mu \mathrm{g} / \mathrm{L}$ in the age groups 12-16 years, 17-21 years, 22-26 years, 2731 years and $>31$ years respectively. Median values of urinary iodine for these groups were $325.26,355.68,325.80,338.86$ and 300.90 respectively. 
Annals of International Medical and Dental Research

E-ISSN: 2395-2822 | P-ISSN: 2395-2814

Vol-8, Issue-1 | January-February 2022

DOI: $10.53339 /$ aimdr.2022.8.1.45

Page no- 358-367 | Section- Research Article (Medicine)

[Table 4] stated that, neither the difference between Mean $\pm S D$ thyroglobulin among male and female $(p=0.294)$ or the difference between Mean $\pm S D$ urinary iodine levels $(p=0.45)$ were statistically significant. Median values for serum thyroglobulin levels were 3.47 and 8.9 respectively for male and female, and median values for urinary iodine levels were 378.1 and 308.9 respectively for male and female.

[Table 5] showed that, neither thyroglobulin $(6.79 \pm 4.33$ vs. $11.67 \pm 13.69, \mathrm{p}=0.319)$ nor urinary iodine $(361.33 \pm 51.60$ vs. $317.09 \pm 182.44, p=0.498)$ were statistically different between the grade-1 and grade-2 goiter groups. Median values of thyroglobulin were 6.74 vs. 8.02 and urinary iodine 362.69 vs. 305.35 .

In [Table 6] showed that, urinary iodine status was categorized into groups as: >300, 200-299, 100-199, 50-99 and $<50 \mu \mathrm{g} / \mathrm{L}$ with concentration of thyroglobulin among the groups as: $12.89 \pm 2.26,9.50 \pm 1.70,6.88 \pm 2.44,11.92 \pm 160$ and $13.61 \pm 8.52$ respectively without any statistically difference among the groups $(p=0.617)$.

[Table 7] showed that, no statistical difference of urinary iodine (302.45 \pm 22.39 vs. 326.74 \pm 23.43 , $\mathrm{p}=0.589$ ) between the different cut off values of serum thyroglobulin.

Table 1: Age distribution of the participants $(\mathrm{N}=87)$

\begin{tabular}{|l|l|l|}
\hline Age group & $\mathbf{n}$ & $\mathbf{\%}$ \\
\hline $12-16$ yrs. & 11 & $12.6 \%$ \\
\hline $17-21$ yrs. & 29 & $33.3 \%$ \\
\hline $22-26$ yrs. & 14 & $16.1 \%$ \\
\hline $27-31$ yrs. & 16 & $18.4 \%$ \\
\hline$>31$ yrs. & 17 & $19.5 \%$ \\
\hline Mean \pm SD & $23.97( \pm 6.83)$ & \\
\hline
\end{tabular}

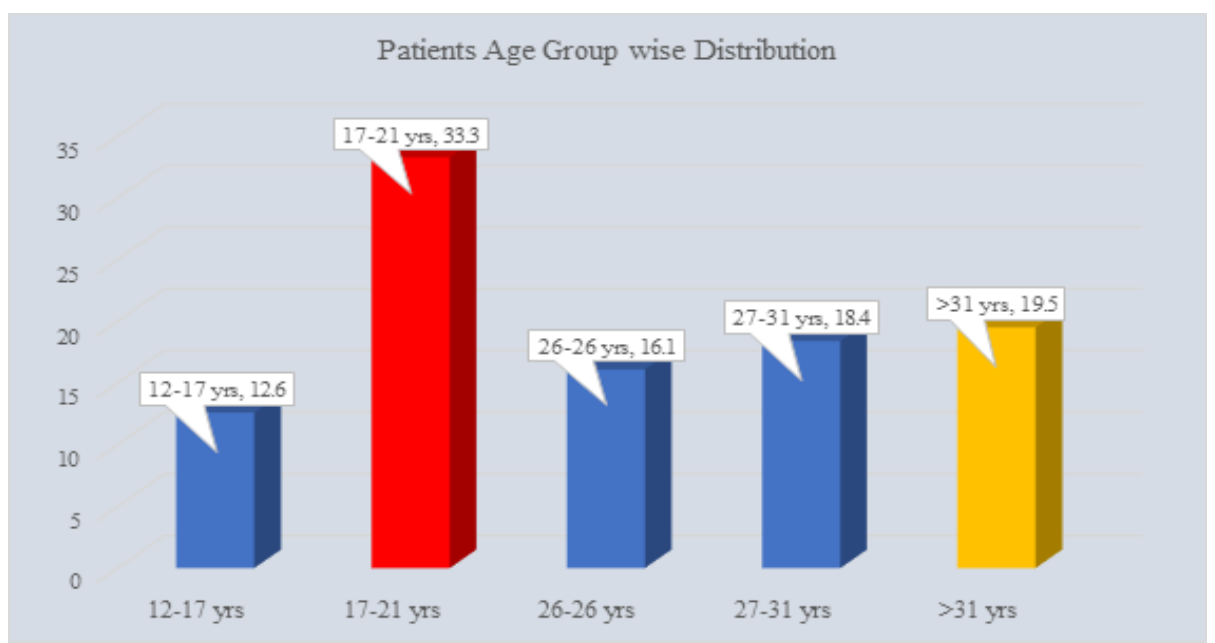

Figure 1: Gender wise distribution of the patients 
Annals of International Medical and Dental Research E-ISSN: 2395-2822 | P-ISSN: 2395-2814

Vol-8, Issue-1 | January-February 2022 DOI: 10.53339/aimdr.2022.8.1.45 Page no- 358-367 | Section- Research Article (Medicine)

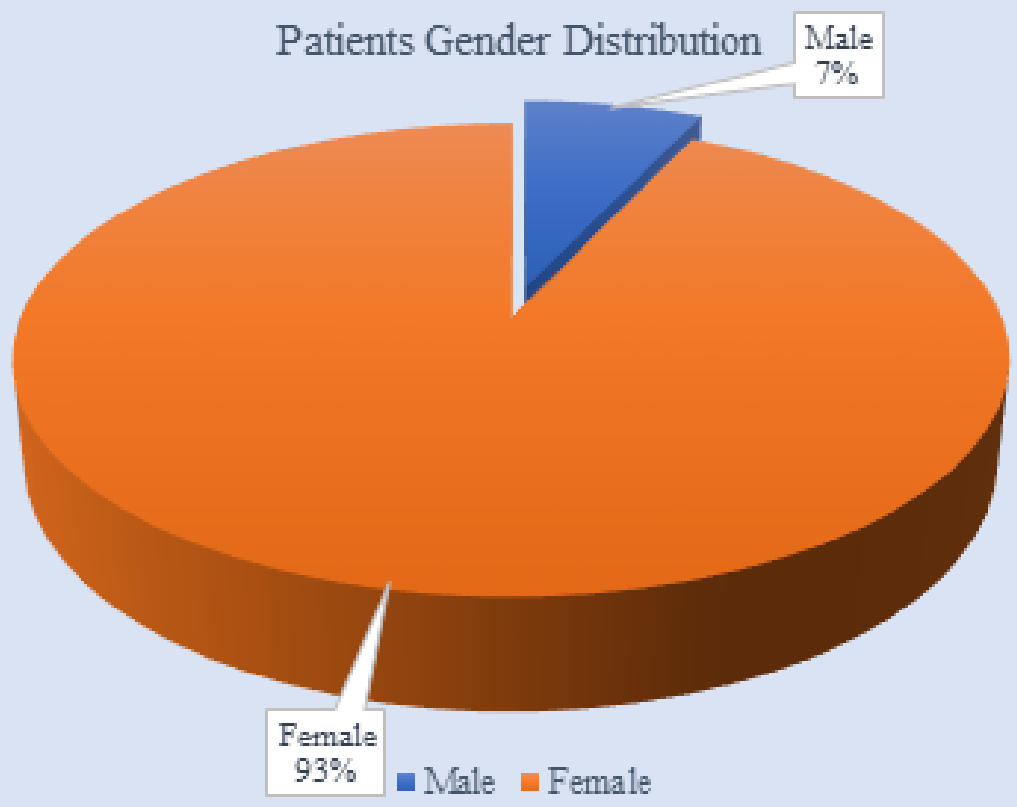

Figure 2: Gender wise distribution of the patients

Table 2: Serum Thyroglobulin $(\mathrm{ng} / \mathrm{mL})$ in different age groups $(\mathrm{N}=87)$

\begin{tabular}{|l|l|l|}
\hline \multirow{2}{*}{ Age group (years) } & Serum Thyroglobulin \\
\cline { 2 - 3 } & Mean \pm SEM & Median \\
\hline $12-16$ yrs. & $6.0 \pm 4.5$ & 5.16 \\
\hline $17-21$ yrs. & $12.9 \pm 18.0$ & 9.42 \\
\hline $22-26$ yrs. & $12.8 \pm 12.2$ & 10.63 \\
\hline $27-31$ yrs. & $12.9 \pm 11.4$ & 9.79 \\
\hline$>31$ yrs. & $8.8 \pm 8.1$ & 6.16 \\
\hline P-Value & 0.52 & \\
\hline
\end{tabular}

Table 3: Urinary Iodine $(\mu \mathrm{g} / \mathrm{L})$ in different age groups $(\mathrm{N}=87)$

\begin{tabular}{|l|l|l|}
\hline \multirow{2}{*}{ Age group (years) } & Urinary iodine $(\boldsymbol{\mu g} / \mathrm{L})$ & Median \\
\cline { 2 - 3 } & Mean \pm SEM & 325.26 \\
\hline $12-16$ yrs. & $347.4 \pm 226.5$ & 355.68 \\
\hline $17-21$ yrs. & $337.08 \pm 188.9$ & 325.8 \\
\hline $22-26$ yrs. & $300.5 \pm 95.37$ & 338.86 \\
\hline 27-31 yrs. & $337.7 \pm 225.4$ & 300.9 \\
\hline P-Value & $278.3 \pm 105.7$ & \\
\hline
\end{tabular}


Annals of International Medical and Dental Research

E-ISSN: 2395-2822 | P-ISSN: 2395-2814

Vol-8, Issue-1 | January-February 2022

DOI: 10.53339/aimdr.2022.8.1.45

Page no- 358-367 | Section- Research Article (Medicine)

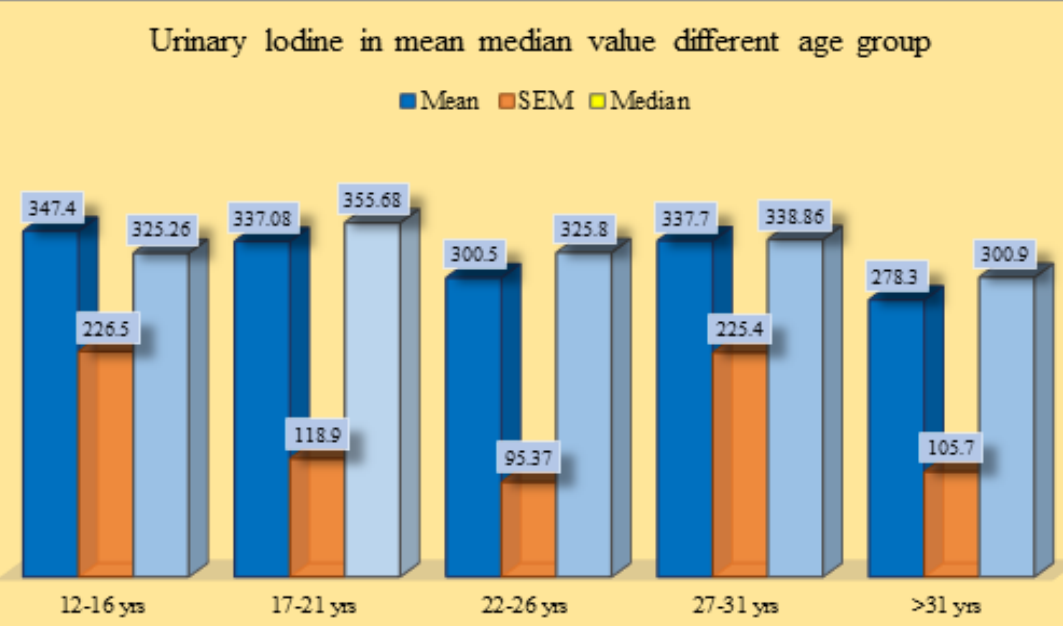

Figure 3: Urinary lodine in mean median value different age group

Table 4: Serum Thyroglobulin $(\mathrm{ng} / \mathrm{mL})$ and Urinary Iodine $(\mu \mathrm{g} / \mathrm{L})$ in different gender groups $(\mathrm{N}=87)$

\begin{tabular}{|l|l|l|l|l|}
\hline Serum Category & Mean/ Median & Male(n=6) & Female (n=81) & P-Value \\
\hline \multirow{2}{*}{ Serum Thyroglobulin $(\mathrm{ng} / \mathrm{ml})$} & Mean \pm SD & $5.76 \pm 5.72$ & $11.60 \pm 13.50$ & 0.294 \\
\cline { 2 - 5 } & Median & 3.47 & 8.9 & \\
\hline \multirow{2}{*}{ Urinary Iodine $(\mu \mathrm{g} / \mathrm{L})$} & Mean \pm SD & $373.5 \pm 44.5$ & $317.2 \pm 180.32$ & 0.45 \\
\cline { 2 - 5 } & Median & 378.1 & 308.9 & \\
\hline
\end{tabular}

Table 5: Serum Thyroglobulin $(\mathrm{ng} / \mathrm{ml})$ and Urinary Iodine $(\mu \mathrm{g} / \mathrm{L})$ in different Grades of goiter $(\mathrm{N}=87)$

\begin{tabular}{|l|l|l|l|l|}
\hline Serum Category & Mean/ Median & Grade-1 (n=8) & Grade-2 (n=79) & P-Value \\
\hline \multirow{2}{*}{ Serum Thyroglobulin $(\mathrm{ng} / \mathrm{ml})$} & Mean \pm SD & $6.79 \pm 4.33$ & $11.67 \pm 13.69$ & 0.319 \\
\cline { 2 - 6 } & Median & 6.74 & 8.02 & \\
\hline \multirow{2}{*}{ Urinary Iodine $(\mu \mathrm{g} / \mathrm{L})$} & Mean \pm SD & $361.33 \pm 51.60$ & $317.09 \pm 182.44$ & 0.498 \\
\cline { 2 - 6 } & Median & 362.69 & 305.35 & \\
\hline
\end{tabular}

Table 6: Serum Thyroglobulin under various cut-off values of Urinary Iodine concentration $(\mu \mathrm{g} / \mathrm{L})$ $(\mathrm{N}=87)$

\begin{tabular}{|l|l|}
\hline Iodine Status $(\mathbf{m g} / \mathrm{L})$ & Serum Thyroglobulin $(\mathbf{n g} / \mathbf{m L}$, Mean $\mathbf{\text { SEM}})$ \\
\hline UIC $>300(\mathrm{n}=49)$ & $12.89 \pm 2.26$ \\
\hline UIC 200-299 $(\mathrm{n}=17)$ & $9.50 \pm 1.70$ \\
\hline UIC 100-199 $(\mathrm{n}=14)$ & $6.88 \pm 2.44$ \\
\hline UIC 50-99 $(\mathrm{n}=4)$ & $11.92 \pm 1.60$ \\
\hline UIC $<50(\mathrm{n}=3)$ & $13.61 \pm 8.52$ \\
\hline P-Value & 0.617 \\
\hline
\end{tabular}




\section{Serum Thyroglobulin under various cut-off values}

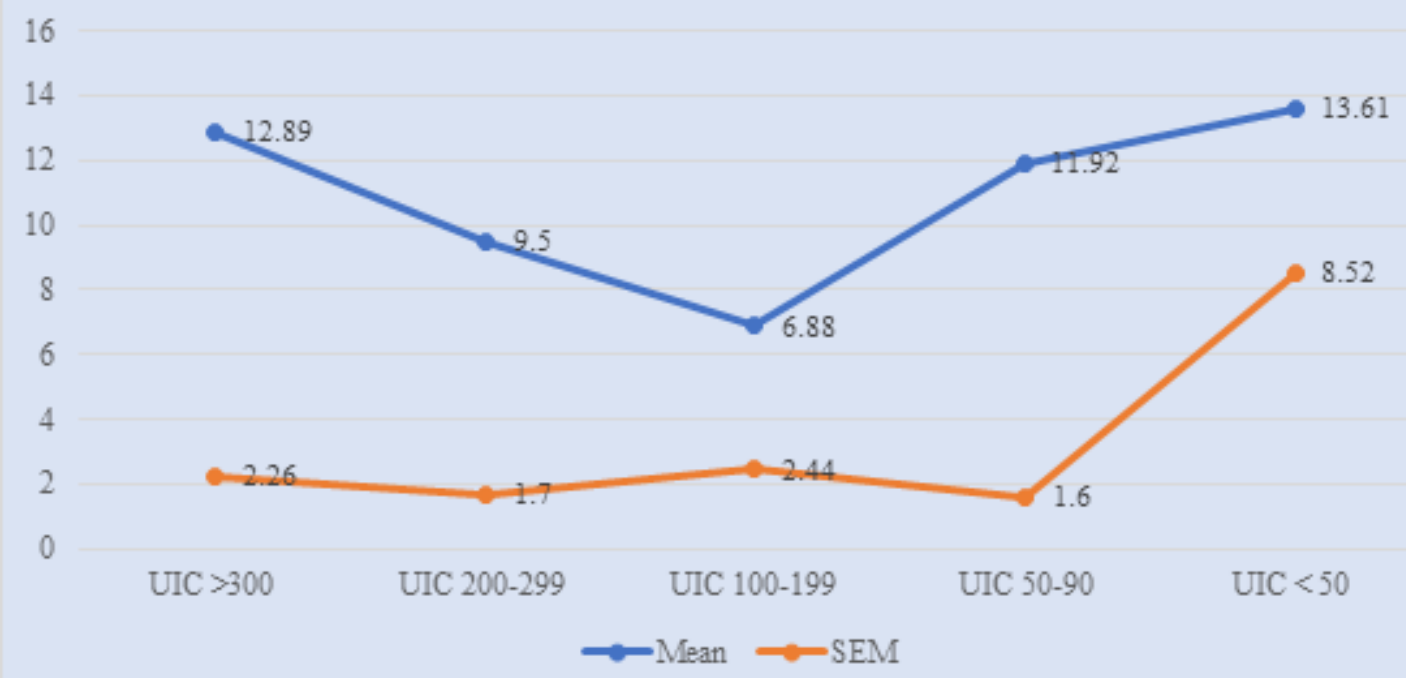

Figure 4: Serum Thyroglobulin under various cut-off values

Table 7: Urinary Iodine $(\mu \mathrm{g} / \mathrm{L})$ in subjects divided by thyroglobulin cut-off $14.46(\mathrm{ng} / \mathrm{ml})(\mathrm{N}=87)$

\begin{tabular}{|l|l|l|}
\hline Thyroglobulin cut-off & Urinary iodine (mean + SEM) & P-Value \\
\hline Thyroglobulin $>14.46 \mathrm{ng} / \mathrm{ml}(\mathrm{n}=20)$ & $302.45 \pm 22.39$ & 0.589 \\
\cline { 1 - 2 } Thyroglobulin $<14.46 \mathrm{ng} / \mathrm{ml}(\mathrm{n}=67)$ & $326.74 \pm 23.43$ & \\
\hline
\end{tabular}

\section{DISCUSSION}

Goiter is a disorder that causes the thyroid gland to enlarge. The thyroid gland is a tiny butterfly-shaped gland in the neck, just below the Adam's apple. Thyroxine (also known as T4) and triiodothyronine are hormones produced by the thyroid gland (also called T3). There are two main types of goiters, the diffuse type and the nodular type. The gland is enlarged two to three times its usual size in simple diffuse goiter, diffuse nontoxic goiter, or colloid goiter. Tenderness, lymphadenopathy, or an overlaying bruit do not exist. T3, T4, and TSH levels in the serum are normal, and no thyroid autoantibodies have been found. Because of iodine prophylaxis, the epidemiology of endemic goiter has altered dramatically.
Nonetheless, the issue continues to remain. Several endemic regions still exist, particularly in rural areas and poor countries. Because the situation fluctuates from year to year, a global partnership of health authorities and researchers is required to create a map of the global occurrence of endemic goiter. An estimated 2 billion individuals worldwide are at risk of iodine deficiency illnesses. 655 million people are goitrous, with 313 million living in South East Asia, and 20 million suffering from varied degrees of mental impairment due to iodine deficiency. Iodine is a trace element that is necessary for the creation of thyroid hormone. These hormones control a wide range of functions, including energy conversion via an influence on oxygen intake and heat generation, development, reproduction, neuromuscular 
Annals of International Medical and Dental Research

E-ISSN: 2395-2822 | P-ISSN: 2395-2814

Vol-8, Issue-1 | January-February 2022

DOI: 10.53339/aimdr.2022.8.1.45

Page no- 358-367 | Section- Research Article (Medicine)

function, skin and hair growth, and cellular metabolism. Iodine deficiency illnesses include goiter, hypothyroidism, increased vulnerability to radiation, and reduced mental function in people of all ages. However, pregnant women, nursing moms, and newborns are the most susceptible populations.[11] On the contrary, excessive iodine intake may, in susceptible individuals, lead to the inhibition of thyroid hormone synthesis. This effect is called the "Wolff Chaikhoff" effect.[12] Excessive intake of iodine can be of iatrogenic origin. But it may be due to use of radio iodine for diagnostic or curative purpose. A similar excess of iodine intake by previously iodide deficient individuals with thyroid autonomy may result in hyperthyroidism. The present study was a cross sectional study carried out in a tertiary care hospital with the aim to observe the impact of thyroglobulin level over the assessment of iodine nutrition status reflected by urinary iodine in simple diffuse goiter patients. Most of the subjects in the present study were iodine sufficient according to the defined criteria. Therefore, the link of thyroglobulin and deficient iodine status could not be properly apprehended by the available data. Female prevalence was extremely high among the participants. The age of the participants was varied, but most of the participants were younger than 30 years, and the Mean \pm SD age was $23.97 \pm 6.83$ years in the present study. In our study, out of 87 participants only 7 were found to be iodine deficient. We did not find any statistically significant differences of mean thyroglobulin concentrations among different age groups. This was similar to the findings of another study.113] However, both mean and median urinary iodine level in different age groups showed a value around $300 \square \mathrm{g} / \mathrm{L}$ though thyroglobulin level exerted relatively higher mean and median values in the age groups within 17-31 years (mean value around $13 \mathrm{ng} / \mathrm{ml}$, median value around $10 \mathrm{ng} / \mathrm{ml})$. On the other hand, subgroups with age $<17$ years and $>31$ years showed lower mean and median values. Therefore, it is pertinent to assume that the age of the participants is unlikely to influence over the pattern of thyroglobulin observed in subgroups of urinary iodine status as described above. Rather, the thyroglobulin pattern was found to be elliptical for the age groups. Serum thyroglobulin level was found to be higher in the females in regards to both the mean and median values. Conversely, urinary iodine (mean and median) was lower in females. Similar findings were observed in another study. ${ }^{[14]}$ From this point of view, it can be extrapolated that decrement of iodine is somehow associated with increase of thyroglobulin. Neither thyroglobulin nor urinary iodine were statistically different between the grade- 1 and grade- 2 goiter groups. Serum thyroglobulin can be elevated due to large thyroid mass, thyroid inflammation or when TSH stimulates the thyroid. The generally increased thyroid mass found under iodinedeficient conditions most likely explains part of the elevation of serum thyroglobulin. However, thyroid volume alone does not explain the elevation of serum thyroglobulin found in iodine-deficient regions; elevated thyroglobulin is also found among subjects without goiter living in iodine deficient areas.[15] Also, serum thyroglobulin has been demonstrated to be associated with various measures of iodine intake.[16] This suggests thyroglobulin to be associated with the iodine nutrition status in the population, independently from the association with thyroid volume. As opposed to urinary 
Annals of International Medical and Dental Research

E-ISSN: 2395-2822 | P-ISSN: 2395-2814

Vol-8, Issue-1 | January-February 2022

DOI: 10.53339/aimdr.2022.8.1.45

Page no- 358-367 | Section- Research Article (Medicine)

iodine concentration, serum thyroglobulin shows only little day-to-day variation. $17,18,19]$ This was reflected when the thyroglobulin and urinary iodine were observed in view of grade of goiter in our study. Urinary iodine was relatively lower than that of grade-1 goiter in regards to both mean and median values. As is conventionally believed, diffuse goiter is triggered by iodine deficient status and gradually enlarges as deficiency persists. From the present findings of urinary iodine level in the different grades of goiter, it seems that subjects in the present study with grade-2 goiter had experienced such events for a longer time than those with grade-1 goiter; though in both cases the iodine level is far higher than the cutoff for the deficiency of the iodine. Accordingly, thyroglobulin was also found to be lower in grade-1 than grade-2 goiter, supporting an inverse relationship of thyroglobulin and urinary iodine as postulated by some authorities. Also, it reflects in other way that larger the goiter increased is the level of thyroglobulin as observed by some other authorities. [20]

\section{Limitations of the study}

The study was conducted in a single hospital with small sample size. So, the results may not

\section{REFERENCES}

1. Ciarrocca M, Tomei F, Caciari T, Cetica C, Andrè JC, Fiaschetti M, Schifano MP, Scala B, Scimitto L, Tomei $\mathrm{G}$, Sancini A. Exposure to arsenic in urban and rural areas and effects on thyroid hormones. Inhal Toxicol. 2012;24(9):589-98. doi: 10.3109/08958378.2012.703251.

2. Delange F, Bürgi H, Chen ZP, Dunn JT. World status of monitoring iodine deficiency disorders control programs. Thyroid. 2002;12(10):915-24. doi: 10.1089/105072502761016557. represent the whole community. Anti-thyroid antibodies and ultrasonography of the thyroid gland could not be done due to financial constraints.

\section{CONCLUSIONS}

Serum thyroglobulin is a good marker of iodine intake and is raised according to the level of iodine insufficiency. Serum thyroglobulin was found to be positively correlated with iodinedeficient areas. However, a slight increase in both mean and median values of thyroglobulin is shown in the subgroups with low and excessive iodine intake which resulting a partial U shaped curve. We did not find statistically significant differences of thyroglobulin concentration between male and female patieents. There was no statistically significant difference of thyoglobulin concentration found between Grade-1 and Grade-2 goiter.

\section{Recommendation}

Mass scale study is required to explore the impact of serum thyroglobulin as a marker of iodine nutritional status. A study with focused iodine deficient study sample needs to be conducted.

3. Zimmermann MB. Iodine deficiency. Endocr Rev. 2009;30(4):376-408. doi: 10.1210/er.2009-0011.

4. Pandav CS, Yadav K, Srivastava R, Pandav R, Karmarkar MG. Iodine deficiency disorders (IDD) control in India. Indian J Med Res. 2013;138(3):418-433.

5. Pandav CS, Yadav K, Srivastava R, Pandav R, Karmarkar MG. Iodine deficiency disorders (IDD) control in India. Indian J Med Res. 2013;138(3):418-433.

6. Bonnema SJ, Nielsen VE, Hegedüs L. Long-term effects of radioiodine on thyroid function, size and patient satisfaction in non-toxic diffuse goitre. Eur J 
Annals of International Medical and Dental Research

E-ISSN: 2395-2822 | P-ISSN: 2395-2814

Vol-8, Issue-1 | January-February 2022

DOI: 10.53339/aimdr.2022.8.1.45

Page no- 358-367 | Section- Research Article (Medicine)

\section{Endocrinol.} 10.1530/eje.0.1500439.

7. Chandrasekaran M, Ramadevi K. Thyromegaly and iodine nutritional status in a tertiary care hospital in South India. Indian J Endocrinol Metab. 2013;17(2):260-264. doi:10.4103/2230-8210.109701

8. Valente VB, Verza FA, Lopes FYK, Ferreira JZ, Dos Santos PSP, Sundefeld MLMM, et al. Stress hormones concentrations in the normal microenvironment predict risk for chemically induced cancer in rats. Psychoneuroendocrinology. 2018;89:229-238. doi: 10.1016/j.psyneuen.2017.11.001.

9. Knudsen N, Bülow I, Jørgensen T, Perrild H, Ovesen L, Laurberg P. Serum Tg--a sensitive marker of thyroid abnormalities and iodine deficiency in epidemiological studies. J Clin Endocrinol Metab. 2001;86(8):3599-603. doi: 10.1210/jcem.86.8.7772.

10.Zimmermann MB, Aeberli I, Andersson M, Assey V, Yorg JA, Jooste $\mathrm{P}$, et al. Thyroglobulin is a sensitive measure of both deficient and excess iodine intakes in children and indicates no adverse effects on thyroid function in the UIC range of 100-299 $\mu \mathrm{g} / \mathrm{L}$ : a UNICEF/ICCIDD study group report. J Clin Endocrinol Metab. 2013;98(3):1271-80. doi: 10.1210/jc.2012-3952.

11.Elliott TC. Iodine deficiency disorders. Health Technol Dir. 1987;7(1):1-12.

12. Kirsten D. The thyroid gland: physiology and pathophysiology. Neonatal Netw. 2000;19(8):11-26. doi: 10.1891/0730-0832.19.8.11.

13.Sun X, Shan Z, Teng W. Effects of increased iodine intake on thyroid disorders. Endocrinol Metab (Seoul). 2014;29(3):240-247. doi:10.3803/EnM.2014.29.3.240

14. Bílek R, Čeřovská J, Zamrazil V. The relationship between iodine intake and serum thyroglobulin in the general population. Physiol Res. 2015;64(3):345-53. doi: 10.33549 / physiolres.932840.

15. Van Herle AJ, Hershman JM, Hornabrook RW, Chopra IJ. Serum thyroglobulin in inhabitants of an endemic goiter region of New Guinea. J Clin Endocrinol Metab. 1976;43(3):512-6. doi: 10.1210/jcem-43-3-512.

16. Rasmussen LB, Ovesen L, Bülow I, Jørgensen T, Knudsen N, Laurberg $\mathrm{P}$, et al. Relations between various measures of iodine intake and thyroid volume, thyroid nodularity, and serum thyroglobulin. Am J Clin Nutr. 2002;76(5):1069-76. doi: 10.1093/ajcn/76.5.1069.

17. Andersen S, Pedersen KM, Pedersen IB, Laurberg P. Variations in urinary iodine excretion and thyroid function. A 1-year study in healthy men. Eur J Endocrinol. 2001;144(5):461-5. doi: 10.1530/eje.0.1440461.

18. Rasmussen LB, Ovesen L, Christiansen E. Day-to-day and within-day variation in urinary iodine excretion. Eur J Clin Nutr. 1999;53(5):401-7. doi: 10.1038/sj.ejcn.1600762.

19. Van Herle AJ, Vassart G, Dumont JE. Control of thyroglobulin synthesis and secretion. (First of two parts). N Engl J Med. 1979;301(5):239-49. doi: 10.1056/NEJM197908023010504.

20. Vejbjerg P, Knudsen N, Perrild H, Laurberg P, Carlé A, Pedersen IB, et al. Thyroglobulin as a marker of iodine nutrition status in the general population. Eur J Endocrinol. 2009;161(3):475-81. doi: 10.1530/EJE-090262 .

Source of Support: Nil, Conflict of Interest: None declared 